\title{
Potensi Asam Amino pada Tempe untuk Memperbaiki Profil Lipid dan Diabetes Mellitus
}

\section{Potency of Amino Acid in Tempeh for Improving Lipid Profile and Diabetes Mellitus}

\author{
Diah M. Utari* Rimbawan ${ }^{* *}$ Hadi Riyadi** Muhilal*** Purwantyastuti*****
}

\begin{abstract}
*Departemen Gizi Kesehatan Masyarakat FKM UI, **Departemen Gizi Masyarakat Fakultas Ekologi Manusia Institut Pertanian Bogor, ****Puslitbang Gizi dan Makanan Kementerian Kesehatan RI, ****Departemen Farmakologi Fakultas Kedokteran UI
\end{abstract}

\begin{abstract}
Abstrak
Prevalensi penyakit degeneratif dari tahun ke tahun meningkat akibat perubahan gaya hidup, khususnya perubahan pola makan. Walaupun tempe sebagai makanan tradisional Indonesia yang banyak dikonsumsi masyarakat karena mudah diperoleh dan harga terjangkau, tidak banyak yang mengetahui manfaat tempe bagi kesehatan. Tempe lama dikenal sebagai sumber protein yang dikonsumsi oleh kalangan masyarakat berpenghasilan rendah. Kajian lebih mendalam mengenai kandungan gizi dan manfaat tempe dan bagi kesehatan, khusus sebagai pencegah penyakit degeneratif perlu dilakukan. Proses fermentasi kedelai menjadi tempe mengakibatkan perubahan zat gizi dan non gizi yang mengakibatkan manfaat tempe jauh lebih baik dibandingkan kedelai. Protein tempe lebih mudah di cerna tubuh, sedangkan asam amino arginin yang meningkat hampir dua kali lipat pada tempe, sangat tinggi manfaatnya bagi kesehatan terutama dalam memperbaiki profil lipid dan diabetes mellitus. Mempertimbangkan hal tersebut tempe dapat dipertimbangkan sebagai pangan fungsional yang bermanfaat bagi kesehatan.
\end{abstract}

Kata kunci: Tempe, protein, arginin, profil lipid, diabetes mellitus

\begin{abstract}
Degenerative diseases prevalence had been arining over years. One of the causes is the life style changes including eating pattern. Tempeh, an Indonesian soybean traditionally fermented food, was known and consumed by almost all Indonesian people. However, only a few know the health benefit of tempeh. Tempeh was also welknown and cheap protein source food affordable for the poor. Hence, there is a need to explore the nutritious content of tempeh and health benefit of it deeper such as in preventing degenerative diseases. Fermentation process of soybean to become tempeh had improved nutrient and non-nutrient contents that make tempeh better than soybean. Tempeh protein is more digestible than soybean and the arginine content increases twice, that could improve lipid profile and diabetes mellitus. Tempeh could be considered as functional food
\end{abstract}

having health benefit.

Key words: Tempeh, protein, arginine, lipid profile, diabetes mellitus

\section{Pendahuluan}

Indonesia dihadapkan pada masalah gizi ganda, masalah gizi kurang masih belum terselesaikan dan masalah gizi lebih serta penyakit degeneratif mulai mengalami peningkatan yang memprihatinkan. Masalah gizi lebih berupa kelebihan berat badan dan obesitas biasanya disertai profil lipid yang memburuk akan diikuti dengan kejadian penyakit degeneratif seperti stroke, diabetes mellitus, atherosklerosis, hipertensi, dan penyakit jantung koroner (PJK). Berdasarkan Riskesdas 2010, ditemukan prevalensi gizi lebih dan obesitas pada dewasa $(19,1 \%)$, penyakit jantung $(7,2 \%)$, diabestes mellitus $(1,1 \%)$, hipertensi $(29,8 \%)$ dan stroke $(0,8 \%)$ tergolong tinggi. ${ }^{1}$ Gizi lebih dan obesitas berisiko sangat tinggi terhadap kejadian profil lipid buruk yang ditandai dengan kolesterol total, kolesterol LDL (K-LDL), trigiliserida serta rendahnya kolesterol-HDL (K-HDL) yang tinggi. Gizi lebih, profil lipid yang buruk dan penyakit degeneratif disebabkan oleh perubahan gaya hidup, khususnya perubahan pola makan dari makanan tinggi serat dan karbohidrat menjadi tinggi lemak dan natrium serta rendah serat. Hal tersebut akan meningkatkan risiko diabetes mellitus yang akhir-akhir ini banyak disoroti berbagai media mengingat prevalensi yang melonjak tinggi, tersebut dikhawatirkan berdampak pada peningkatan

Alamat Korespondensi: Diah M. Utari, Departemen Gizi Kesehatan Masyarakat FKM Universitas Indonesia Gd. F Lt. 2 Kampus Baru UI Depok 16424,Hp.08164817164,e-mail:diah-fkm@ui.ac.id 
penyakit jantung, gagal ginjal, katarak dan meningkatkan risiko kematian.

Sebagai makanan sumber protein nabati, kedelai merupakan komponen penting dalam diet penduduk di wilayah Asia dan diketahui merupakan faktor lingkungan yang menonjol dalam pencegahan penyakit degeneratif. ${ }^{2}$ Hasil penelitian di berbagai populasi di banyak negara menunjukkan bahwa protein kedelai menurunkan kolesterol plasma, triasilgliserol, dan glukosa darah, dan berperan sebagai antioksidan yang potensial serta memperbaiki fungsi endothelial koroner. 3,4 Selama 60 tahun terakhir, diketahui bahwa mengganti konsumsi hewani dengan protein kacang-kacangan dapat memperbaiki profil lipid dan mencegah atherosklerosis. Dalam 10-12 tahun terakhir penelitian tentang protein kacang-kacangan yang semakin meningkat dan mendalam membuktikan bahwa konsumsi protein memperbaiki beberapa aspek kesehatan termasuk diabetes mellitus dan kesehatan jantung. Suatu meta analisis pada tahun 1966 sampai 2005 menjelaskan bahwa suplementasi protein kedelai berpengaruh bermakna pada penurunan kolesterol total, K-LDL dan trigliserida serta meningkatkan K-HDL. ${ }^{5}$ Protein kedelai memperbaiki profil lipid penduduk dewasa pada individu dengan profil lipid normal dan hiperkolesterolemia. Dengan demikian, mengganti makanan tinggi lemak jenuh, lemak trans dan kolesterol dengan protein kedelai berpengaruh menguntungkan pada faktor risiko penyakit jantung koroner.

Peranan memperbaiki profil lipid dan glukosa darah terlihat lebih menguntungkan pada konsumsi matriks protein kedelai atau protein kedelai bentuk utuh daripada konsentrat protein atau konsentrat non gizi dalam kedelai. ${ }^{6}$ Meskipun peran komponen kedelai secara individu terhadap lemak tidak sepenuhnya dimengerti, protein kedelai diduga dapat mempengaruhi metabolisme hepatik dari kolesterol atau lipoprotein atau pengaturan reseptor LDL. ${ }^{7}$

Indonesia termasuk salah satu negara pengonsumsi kedelai yang tinggi dengan kebutuhan kedelai mencapai 2,4 juta ton per tahun. Sekitar $50 \%$ dari kedelai tersebut diolah menjadi tempe melalui proses fermentasi dengan penambahan Rhizopus oligosporus yang merupakan makanan tradisional yang sangat popular. ${ }^{8}$ Tempe sangat terkenal di kalangan masyarakat kelas menengah ke bawah karena harga yang sangat terjangkau. Kini, tempe dipertimbangkan sebagai pangan fungsional (functional food) karena kandungan gizi dan substansi yang aktif dengan komposisi gizi yang lebih baik daripada kedelai. Namun, kuantitas konsumsi tempe di Indonesia masih tergolong rendah, kurang dari $7 \mathrm{~kg} / \mathrm{kap} /$ tahun. Sementara, hampir semua negara di dunia yang mengonsumsi tempe mengalami peningkatan. Sebagai akibat pemahaman tentang hidup sehat dan penganut vegetarian yang mengonsumsi tempe sebagai pengganti daging semakin meningkat.

Pemilihan tempe sebagai bahan penelitian dilakukan dengan beberapa pertimbangan. Dari aspek produsen, kedelai merupakan bahan dasar pembuat tempe yang mudah didapatkan, proses pengolahan sederhana, mudah dipasarkan, dan keuntungan membuat tempe sekitar 30\% berharga murah, mudah didapat di pasar, mudah diolah menjadi makanan, dan merupakan makanan yang umum dikonsumsi masyarakat. Selain itu, tempe dengan kandungan gizi dan non gizi yang melebihi kedelai sangat bermanfaat bagi kesehatan. Namun, sampai demikian jauh zat gizi yang terkandung di dalam tempe dan berperan penting bagi kesehatan belum banyak diketahui masyarakat. Penelitian ini bertujuan menganalisis kandungan protein dan asam amino dalam tempe dan melakukan kajian terhadap makanan yang bermanfaat bagi perbaikan profil lipid dan diabetes mellitus. Mengingat keduanya merupakan faktor risiko penyakit jantung koroner (PJK) yang menjadi penyebab utama kematian di Indonesia.

\section{Metode}

Bahan yang digunakan dalam analisis adalah tempe kukus karena dianggap berpengaruh paling rendah terhadap perubahan zat gizi dan substansi aktif dalam tempe. Selain itu, masyarakat umumnya mengonsumsi tempe yang telah diolah karena tidak lazim untuk mengonsumsi tempe mentah. Analisis protein dan asam amino tempe kukus dilakukan di Laboratorium Terpadu Institut Pertanian Bogor, Jawa Barat. ${ }^{9}$ Prinsip kerja analisis protein adalah senyawa nitrogen dalam protein diubah menjadi amonium sulfat oleh $\mathrm{H}_{2} \mathrm{SO}_{4}$ pekat. Amonium sulfat yang terbentuk diuraikan dengan larutan $\mathrm{NaOH}$ pekat $(30 \% \mathrm{~b} / \mathrm{v})$. Amonium yang dibebaskan diikat dengan asam borat berlebih dan kemudian di titar dengan larutan $\mathrm{HCl}$. Prinsip analisis asam amino adalah hasil analisis asam amino ditingkatkan dengan memanfaatkan reaksi prakolom gugus amino dengan pereaksi tertentu hingga membentuk derivat yang dapat menyerap sinar UV atau berflouresensi. Salah satu pereaksi pra kolom yang popular dalam analisis asam amino adalah ortoftalaldehida (OPA). Zat ini bereaksi dengan asam amino primer dalam suasana basa yang mengandung merkaptoetanol membentuk senyawa yang berfluoresensi dan dideteksi dengan detektor flouresensi. Hasil analisis laboratorium dikaji lebih mendalam berdasarkan penelitian/pustaka terkait, sehingga secara ilmiah manfaat tempe bagi kesehatan khususnya pencegahan penyakit dapat diketahui.

\section{Hasil}

Analisis kadar protein menunjukkan bahwa dalam 100 gram tempe kukus mengandung $16,85 \% \mathrm{w} / \mathrm{w}$ protein. Pengukusan selama 10 menit menambah kadar air 
Tabel 1. Kandungan Protein dan Asam Amino per 100 gram Tempe Kukus

\begin{tabular}{ll}
\hline Parameter & $\begin{array}{c}\text { Hasil } \\
\text { Bw/w Berat Basah }\end{array}$ \\
\hline Protein & 16,85 \\
Asam Amino & \\
$\quad$ Arginine & 6,58 \\
Glutamic acid & 1,74 \\
Aspartic acid & 1,13 \\
Serine & 0,50 \\
Histidine & 0,31 \\
Glycine & 0,42 \\
Threonine & 0,44 \\
Alanine & 0,47 \\
Tyrosine & 0,40 \\
Methionine & 0,15 \\
Valine & 0,58 \\
Phenylalanine & 0,53 \\
I-leucine & 0,51 \\
Leucine & 0,76 \\
Lysine & 0,95 \\
Tryptophane & 0,13 \\
\hline
\end{tabular}

sekitar 4\% - 5\%, sehingga dalam 100 gram tempe mentah mengandung $17,7 \% \mathrm{w} / \mathrm{w}$ protein. Asam amino yang dominan pada tempe adalah arginin yang pada penelitian ini merupakan asam amino dengan kadar tertinggi, $(6,58 \% \mathrm{w} / \mathrm{w})$ (Lihat Tabel 1).

\section{Pembahasan}

\section{Kadar Protein dan Asam Amino}

Hasil analisis pada studi ini menunjukkan bahwa kadar protein dalam 100 gram tempe mentah (berat basah) adalah 17,7\%w/w, sedikit lebih rendah dibandingkan kandungan protein tempe yang tertera dalam PERSAGI tahun 2000 sebesar 20,8 gram/100 gram bahan. ${ }^{10}$ Berdasarkan penelitian terdahulu, total kandungan protein kedelai tidak banyak berubah setelah proses fermentasi menjadi tempe, perubahan dalam nitrogen terlarut hanya 0,5\%-2,5\%. ${ }^{11}$ Angka kecukupan gizi (AKG) protein untuk dewasa adalah 50 gram/hari, sehingga konsumsi 100 gram tempe akan memberikan sumbangan protein yang cukup besar, yaitu sekitar 35\% AKG.

Setelah fermentasi, terjadi peningkatan asam amino bebas sebesar 7,3\% hingga 30\%.11,12 Hal tersebut karena selama fermentasi, Rhizopus dan bakteri akan menghasilkan enzim protease, sehingga protein diurai menjadi asam amino bebas. ${ }^{13}$ R.oligosporus akan menghidrolisa protein menjadi asam amino dan peptida. Jumlah asam amino yang dibebaskan mencapai puncaknya setelah fermentasi selama 24 jam hingga 72 jam. ${ }^{14}$ Tempe yang dijual di pasaran pada umumnya melewati masa fermentasi selama 36 jam. Meningkatnya pelepasan asam amino ini akan memperbaiki nilai gizi tempe yaitu protein digestibility corrected amino acid score (PDCAAS) yang mencapai 0,8 - 0,9 atau $80-90 \%$ dari protein hewani. Selama fermentasi, Rhizopus menghasilkan setidaknya empat grup enzim yaitu lipase, protease, amylase, dan phytase yang menguntungkan bagi individu dengan masalah pencernaan. Enzim tersebut juga membantu proses pencernaan protein, lemak, dan karbohidrat. ${ }^{11}$

\section{Pengaruh Asam Amino terhadap Profil Lipid}

Secara umum, protein nabati lebih banyak mengandung asam amino seperti arginin, glisin, dan alanin, sementara protein hewani banyak mengandung lisin dan metionin. Penelitian terdahulu mencatat bahwa asam amino lisin dan metionin cenderung meningkatkan kadar kolesterol, sedangkan arginin memperlihatkan efek yang berlawanan. ${ }^{15}$ Metionin merupakan prekursor homosistein yang merupakan faktor risiko PJK. Hal tersebut menjelaskan penyebab pangan hewani lebih bersifat hiperkolesterolemia daripada pangan nabati. Penelitian lain menjelaskan bahwa semua asam amino esensial kecuali arginin berpotensi hiperkolesterolemia, sedangkan lisin dan methionin merupakan asam amino dengan efek terbesar. ${ }^{16}$

Insulin dan glukagon berperan dalam homeostatis lemak dan glukosa tubuh. Perubahan hormon yang terjadi saat pemberian protein kedelai adalah penurunan rasio insulin/glukagon. ${ }^{17}$ Sedangkan, tingginya rasio insulin/glukagon dihubungkan dengan peningkatan risiko PJK yang disebabkan efek atherogenik dan hiperlipidemik. Penurunan rasio insulin/glukagon merupakan bagian yang bertanggung jawab pada efek hipolipidemik dari protein kedelai. Suatu studi pada binatang yang memberikan intervensi protein kedelai menemukan intervensi protein kedelai pada jangka pendek akan menurunkan serum insulin dan intervensi pada jangka panjang meningkatkan serum glukagon.

Kemampuan protein kedelai mengatur rasio insulin/glukagon dijelaskan oleh komposisi asam amino sedangkan konsentrasi serum glukagon tergantung pada jumlah dan komposisi protein yang dikonsumsi. Tingginya rasio arginin/lisin dihubungkan dengan tingginya konsentrasi serum glukagon atau penurunan sekresi insulin sehingga menghambat lipogenesis. Turunnya plasma insulin oleh protein kedelai disebabkan karena turunnya pelepasan dari pankreas atau peningkatan perpindahan hepatik. ${ }^{18}$ Penelitian tersebut juga menunjukkan bahwa pemberian lisin dan methionin akan meningkatkan phospholipid dalam hati dan peningkatan rasio PC/PE (phosphatidlcholine/phosphatidylethanolamine) dibandingkan jika diberikan arginin. ${ }^{18}$ Diet lisin dan metionin juga meningkatkan kolesterol total dan K-LDL serta apolipoprotein B. Kandungan asam amino dan tocoferol pada tempe bekerja sinergis sebagai antioksidan dalam tubuh. Banyak studi menunjukkan hasil bahwa kedelai mempunyai potensi sebagai penangkal radikal yang lebih 
kuat dibandingkan sayuran lain seperti wortel, buncis, jus buah. ${ }^{19}$ Jika melihat perubahan zat gizi khususnya asam amino tempe yang lebih baik dibandingkan kedelai, maka dapat dikatakan bahwa manfaat antioksidan tempe lebih tinggi dibandingkan kedelai.

Kampanye peningkatan konsumsi nabati nampaknya sudah didengungkan oleh ketetapan U.S. Food and Drug Administration's yang menyebutkan bahwa " 25 gram protein nabati per hari sebagai bagian dari diet rendah SAFA dan kolesterol dapat menurunkan risiko penyakit jantung". ${ }^{20}$ Berbagai uji klinik pada manusia menyebutkan bahwa konsumsi 25 gram hingga 50 gram protein kedelai per hari adalah aman dan efektif menurunkan KLDL sekitar 4\% hingga 8\% dan dapat memperbaiki profil lipid khususnya pada individu yang mengalami hiperkolesterolemia. ${ }^{15}$ Jumlah tersebut kira-kira setara dengan minimal 150 gram tempe setiap hari atau 3 potong tempe ukuran sedang. Pemasakan yang tepat adalah dengan pengukusan atau perebusan dalam waktu singkat tidak lebih dari 10 menit, sehingga zat gizi masih dalam jumlah maksimal. Peran asam amino untuk memperbaiki profil lipid dan antioksidan tersebut dapat menurunkan risiko terkena penyakit jantung koroner.

\section{Pengaruh Asam Amino terhadap Diabetes Mellitus}

Dalam dua dasawarsa terakhir banyak penelitian dilakukan untuk melihat efek pemberian kedelai terhadap hal-hal yang berkaitan dengan penyakit diabetes mellitus. Arginin dihubungkan dengan penyembuhan luka khususnya pada penderita diabetes. Penelitian terdahulu membuktikan bahwa pemberian tempe dalam jangka lama dapat memperbaiki penyembuhan luka pada tikus diabetes. ${ }^{21}$ Mekanisme pengaruh arginin dalam penyembuhan luka adalah bahwa arginin merupakan salah satu bahan pembentuk nitrat oksida (NO) yang akan membantu sintesa kolagen pada daerah yang luka. ${ }^{22}$

Penelitian lain menyebutkan bahwa NO yang disintesa dari arginin akan mengatur metabolisme glukosa, asam lemak dan asam amino, sehingga konsumsi arginin akan menurunkan massa lemak pada tikus yang obesitas dan diabetes. ${ }^{23}$ Nitrat oksida juga meningkatkan transport glukosa, menurunkan sintesa glukosa dan glikogen serta menstimulasi pelepasan insulin. Penelitian lain membuktikan bahwa pemberian ekstrak metanol-tempe pada tikus diabetes dapat menurunkan kadar glukosa darah dan menghambat laju kerusakan sel $\beta$ pakreas. ${ }^{24}$ Daya hipoglikemik disebabkan karena terhambatnya enzim $\alpha$ glukosidase dalam usus sehingga akan memperlambat penguraian karbohidrat menjadi bentuk sederhana dan akibatnya glukosa akan diperlambat pelepasan dan absorbsinya dalam brush border usus.

\section{Kesimpulan}

Arginin adalah asam amino dengan jumlah tertinggi yang terdapat pada tempe yang mempunyai efek untuk memperbaiki profil lipid dan diabetes mellitus. Mekanisme arginin terhadap efek profil lipid adalah melalui mekanisme penurunan lipogenesis. Sedangkan, pada penderita dibetes mellitus, arginin dapat mempercepat penyembuhan luka dengan meningkatkan nitrat oksida, menghambat laju kerusakan sel $\beta$ pakreas dan mempunyai efek hipoglikemia sehingga bermanfaat untuk mencegah memburuknya diabetes mellitus.

\section{Saran}

Adanya kampanye untuk meningkatkan konsumsi tempe sebagai pangan bergizi yang murah dan bermanfaat untuk kesehatan khususnya untuk mencegah memburuknya profil lipid dan mencegah serta memperlambat diabetes mellitus. Sebaiknya minimal dikonsumsi 3 potong tempe ukuran sedang (sekitar 150 gram tempe/hari) dengan pemasakan pengukusan atau perebusan.

\section{Daftar Pustaka}

1. Departemen Kesehatan Republik Indonesia. Laporan hasil riset kesehatan dasar (Riskesdas). Jakarta: Badan Penelitian dan Pengembangan Kesehatan, Departemen Kesehatan Republik Indonesia; 2007.

2. Rimbach G, Boesch-Saadatmandi C, Frank J, Fuchs D, Wenzel U, Daniel H, Hall WL, Weinberg PD. Dietary isoflavones in the prevention of cardiovascular disease - a molecular perspective. Food and Chemical Toxicology. 2007; 46: 1308-19.

3. Palanisamy N, Viswanathan P, Anuradha CV. Effect of genistein, a soy isoflavone, on whole body insulin sensitivity and renal damage induced by a high-fructose diet. Renal Failure. 2008; 30: 645-54.

4. Matthan NR, Jalbert SM, Ausman LM, Kuvin JT, Karas RH, Lichtenstein AH. Effect of soy protein from differently processed products on cardiovascular disease risk factors and vascular endothelial function in hypercholesterolemic subjects. Am J Clin Nutr. 2007; 85:960-6.

5. Reynolds K, Chin A, Lees KA, Nguyen A, Bujnowski D, He J. A metaanalysis of the effect of soy protein supplementation on serum lipids. Am J Cardiol. 2006; 98: 633- 40.

6. Steinberg F, Guthrie N, Villablanca A, Kumar K, Murray M. Soy protein with isoflavones has favorable effects on endothelial function that are independent of lipid and antioxidant affects in healthy postmenopausal women. American Journal of Clinical Nutrition. 2003; 78: 123-30.

7. Anderson JW. Diet first, then medication for hypercholesterolemia. Journal of the American Medical Association. 2003; 290: 531-3.

8. Simatupang P, Marwoto, Swastika D. Pengembangan kedelai dan kebijakan penelitian di Indonesia. Dalam lokakarya Pengembangan kedelai dan lahan sub optimal. Malang: Balitkabi tanggal 26 Juli 2005.

9. AOAC. Dalam panduan analisa. Bogor: Laboratorium Terpadu Institut Pertanian Bogor.

10. Persatuan Ahli Gizi. Tabel komposisi pangan Indonesia. Jakarta; 2009.

11. Hermana, Mahmud M, Karyadi D. Composition and nutritional value of tempe: its role in the improvement of the nutritional value of food. Dalam "The complete handbook of tempe". The American Soybean Association. 1999. 
12. Kiers JL. Effects of fermented soya bean on digestion, absorption and diarrhoea [disertation]. Wageningen University; 2001.

13. Hermana, Mahmud M. The development of tempe technology. Dalam The complete handbook of tempe". The American Soybean Association. 1999.

14. Wang HL, Ruttle DI, Hesseltine CW. Protein quality of wheat and soybeans after rhizopus oligosporus fermentation. J. Nutrition. 1996; 10914.

15. Erdman JJ, Badger T, Lampe J, Setchell KK, Messine M. Not soy products are created equal: caution needed in interpretation of research results. The Journal of Nutrition. 2004; 134: S1229-33.

16. Kurowska EM, Carroll KK. Hypercholesterolemic responses in rabbits to selected groups of dietary essential amino acids. J Nutr. 1994; 124: 364-70.

17. Ham JO, Chapman KM, Essex-Sorlie D, Bakhit RM, Prabhudesai M, Winter L, dkk. Endocrinological response to soy protein and fiber in mildly hypercholesterolemic men. Nutr. Res. 1993; 13: 873-84.

18. Isabelle G, Kurowska EM, Carroll KK. Role o dietary lysine, methionine, and arginine in the regulation of hypercholesterolemia in rabbits.
J. Nutr. Biochem. 1999; 10: 166-71.

19. Wu X, Beecher GR, Holden JM, Haytowitz DB, Gebhardt SERL. Lipophilic and hydrophilic antioxidant capacities of common foods in the United States. J.Agric.Food.Chem. 2004; 52: 4026-37.

20. Food and Drug Administration. Food labelling: health claim, soy protein and coronary hearth disease. Fed Regist. 1999; 57: 699-733. Available from: http://www.fda.gov/bbs/topics/ANSWERS/ANS00980.html.

21. Setiawan GD. Pengaruh diet tempe terhadap kesembuhan luka pada tikus diabetes yang diinduksi streptozotocin (STZ) [skripsi]. Bogor: Faperta Institut Pertanian Bogor; 2008.

22. Abumrad NN and Barbul A. The use of arginin in clinical practice; metabolic and therapeutic aspects of amino acid in clinical nutrition (Luc A. Cynober ed.). New York: CRC; 2003.

23. Shi JW, Fried SK, Fu WJ, Meininger CJ, Wu G. Regulatory role for the arginine-nitric oxide pathway in metabolism of energy substrates. Journal of Nutr. Bioc. 2006; 17:57.

24. Suarsana IN. Aktivitas hipoglikemik dan antioksidatif ekstrak metanol tempe pada tikus diabetes [disertasi]. Bogor: Institut Pertanian Bogor; 2009. 